\title{
Mağduriyetin Sineması: Yunan Yeni Dalgası Üzerine Bir İnceleme
}

\section{Dilan Tüysüz}

\section{ÖZ}

2000 sonrası çağdaş Yunan sinemasını anlamak için söz konusu dönemin sosyal, siyasal, kültürel ve ekonomik gelişmelerine yakından bakmak gerekmektedir. Uluslararası eleştirmen ve akademisyenler tarafından Yunan yeni dalgası ya da Yunan tuhaf dalgası olarak adlandırılan akım, 2008 yılında ülkede yaşanan ekonomik kriz sonrasında çekilen 'tuhaf' filmleri kapsamaktadır. Söz konusu filmler krizle doğrudan ilgili olmamakla birlikte, krizin neden olduğu toplumsal travmayı yansıtır niteliktedir. Akımın tuhaf olarak nitelendirilmesi ise, filmlerin biçimsel ve içerik bakımından geleneksel anlatılardan farklı stratejiler izliyor olmasıyla ilgilidir. Bu çalışma ise, Yunan yeni dalgasının sadece tuhaf değil ama aynı zamanda 'mağduriyet sineması' olarak da düşünülebileceğini savunmaktadır. Ekonomik krizin genç nesil için sebep olduğu maddi ve manevi sıkıntıların yanı sıra, Yunan toplumunun kurucu değerleri olarak kabul edilen 'anayurt, din ve aile' kavramları da bugünün travmalarında rol oynamaktadır. Bu nedenle çalışma, yeni dalga filmlerinin aşırı milliyetçiliğin, geleneksel ahlaki değerlerin ve ataerkil yapının mağdur ettiği bireylerin öykülerini anlattığı düşüncesinden hareketle, mağduriyet temasının da Yunan yeni dalgasının ayırıcı özellikleri arasında olduğunu göstermeyi amaçlamaktadır. Bu kapsamda iki ana bölüme sahip olan çalışmanın ilk bölümünde Yunan yeni dalgasını oluşturan filmlerin ortak karakteristik özellikleri ele alınmıştır. İkinci bölümde ise çalışmanın amacına yönelik olarak Yunan yeni dalgasının önemli örnekleri arasından seçilen sekiz film mağduriyet teması üzerinden incelenmiştir. Çalışmada nitel araştırma yöntemlerinden biri olan betimsel analiz benimsenmiştir. Araştırma sonucunda mağduriyet kavramının Yunan yeni dalgası için tematik bir çerçeve olarak kullanılabileceği görülmüştür.

Anahtar Sözcükler: Yunan Yeni Dalgası, Yunan Sineması, Mağduriyet, Kriz, Yunanistan

\author{
DILAN TÜYSÜZ \\ Dr. Öğr. Üyesi \\ Aydın Adnan Menderes Üniversitesi \\ dilan.tuysuz@adu.edu.tr \\ ORCID ID: 0000-0002-5887-9519
}

SELÇUK ILETIŞIM DERGISI 2021; 14(2): 805-831

doi: 10.18094/JOSC.870677

Geliş Tarihi: 29.01.2021 Kabul Tarihi: 15.03.2021 Yayın Tarihi: 25.04.2021 


\title{
Cinema of Victimization: A review of the Greek New Wave
}

JOURNAL OF SELÇUK

COMMUNICATION 2021;

14(2): $805-831$

doi: 10.18094/ JOSC.870677

[\$]

SEELDIIK

ILETISTM

\section{Dilan Tüysüz}

\begin{abstract}
In order to understand the contemporary Greek cinema after 2000, it is necessary to take a closer look at the social, political, cultural and economic developments of that period. The movement, which is called the Greek new wave or the Greek weird wave by international critics and academics, includes 'weird' movies shot after the economic crisis in the country in 2008. Although the films in question are not directly related to the crisis, they reflect the social trauma caused by the crisis. The weird character of the movement is related to the fact that the films follow different form and content strategies from traditional narratives. This study, on the other hand, argues that the Greek new wave can be considered not only as weird but also as a 'cinema of victimization'. In addition to the financial and moral difficulties caused by the economic crisis for the young generation, the concepts of 'fatherland, religion and family', which are accepted as the founding values of Greek society, also play a role in today's traumas. Therefore, the study aims to show that the theme of victimization is among the distinctive characteristics of the Greek new wave, based on the idea that the new wave films tell the stories of individuals victimized by extreme nationalism, traditional moral values and patriarchal structure. In this context, firstly, the common characteristics of the films of the Greek new wave are discussed. In the second part, eight films selected among the important examples of the Greek new wave for the purpose of the study were examined through the theme of victimization. Descriptive analysis, one of the qualitative research methods, was conducted in the study. As a result of the research, it was seen that the concept of victimization could be used as a thematic framework for the Greek new wave.
\end{abstract}

Keywords: Greek New Wave, Greek Cinema, Victimization, Crisis, Greece

\author{
DILAN TÜYSÜZ \\ Asst. Prof. \\ Aydın Adnan Menderes University \\ dilan.tuysuz@adu.edu.tr \\ ORCID ID: 0000-0002-5887-9519
}

JOURNAL OF SELÇUK COMMUNICATION 2021; 14(2): 805-831

doi: 10.18094/ JOSC.870677 


\section{Gíriş}

Sinema tarihi, filmlerin nasıl üretilmesi gerektiği hakkında alternatif fikirler geliştiren eleştirmenlerin, kuramcıların, yönetmen ve yapımcıların teorilerine dayanan film akımlarıyla şekillenmiştir. İtalyan Yeni Gerçekçiliği, Fransız Yeni Dalgası gibi önemli örnekleri bulunan bu akımlar 'sinema nasıl olmalı' sorusuna sunduğu cevaplarla film üretimini pek çok açıdan etkilemiştir ve etkilemeye devam etmektedir. Yaklaşık 2010 yılından itibaren, uluslararası sinema kültürünü etkileyen, izleyiciyi şaşırtan, rahatsız eden ve düşündüren yeni bir film akımının daha Yunanistan'da doğduğu kabul edilmektedir. Film eleştirmenleri ve akademisyenler tarafından Yunan Yeni Dalgası ya da Yunan Tuhaf Dalgası olarak nitelendirilen bu akım, biçimsel özellikleri ve ele aldıkları meseleler üzerinden övgüler ve eleştiriler almakta ve özel bir ilgiyi hak etmektedir.

Illk olarak, Yorgos Lanthimos'un 2009 yılında Cannes Film Festivali'nde prömiyerini yapan filmi Köpek Dişi (Kynodontas) ve 2010'da Venedik Film Festivali'nde gösterilen Athina Rachel Tsangari'nin yönettiği Attenberg, eleştirmenlerin Yunan sinemasında 'tuhaf' bir şeyler döndüğünü fark etmelerine neden olmuştur. "Tuhaf" nitelendirmesini ilk kullanan isimlerden biri olan Peter Bradshaw (2011), The Guardian gazetesi için yazdığı Attenberg filmiyle ilgili eleştirisinde duruma şöyle dikkat çekmektedir: "Yunan yeni dalgasının son ürünü, sosyal ve ekonomik çöküş içindeki bir ülkenin rahatsız edici zihin durumunu akla getiren ilgi çekici bir tuhaflıktır". Başlıca ortak noktaları filmlerindeki -Bradshaw'ın dikkat çektiği- 'tuhaflık' olan Lanthimos ve Tsangari, bu yeni sinema hareketinin öncüleri olarak kabul edilmiş ve ardından Kadının Fendi (Strella, 2009, yön. Panos H. Koutras), Plato'nun Akademisi (Akidimia Platonos, 2009, yön. Flippos Tsitos), Anavatan (Hora Proelefsis, 2010, yön. Syllas Tzoumerkas), Kesici (Macherougaltis, 2010, yön. Yiannis Economides), Wasted Youth (2011, yön. Argyris Papadimitropoulos), L (2012, yön. Babis Makridis), Kuş Yemi Yiyen Oğlan (To Agori Troei To Fagito Tou Pouliou, 2012, yön. Ektoras Lygizas), Şiddet Güzeli (Miss Violence, 2013, yön. Alexandros Avranas), Matriarchy (2014, yön. Nikos Kornilios) ve Xenia (2015, yön. Panos H. Koutras) gibi filmler Yunan yeni dalgasına katılmaya devam etmiş̧ir.

Yunan yeni dalgası ile ilgili yapılan uluslararası araştırmalarda ve akademik çalışmalarda, bu yeni sinema hareketi ile Yunan toplumunda yaşanan politik, ekonomik ve sosyal gelişmeler arasında bağlantı kurulduğu görülmektedir. Yunan yeni dalgasının bir tür travma ve kayıp duygusunu yansıttığını belirten 
Afroditi Nikolaidou'ya göre bu eğilim ülkenin sosyo-ekonomik atmosferiyle bağlantılıdır (2014). Bu doğrultuda Yunan yeni dalgasını anlamak için 2000 sonrası Yunan toplumundaki gelişmeleri ve özellikle 2008 yılında yaşanan ve Yunanistan'ı da etkileyen Euro Bölgesi krizini incelemek önemlidir. Filmlerin aynı zamanda kültürel ürünler olduğu göz önüne alındığında kriz ve Yunan yeni dalgası arasında ilişki kurmak olanaklıdır. Buna göre, yeni dalga içinde değerlendirilen filmler krizdeki bir toplumdan doğmuştur ve krizdeki bir toplumu, başka bir ifadeyle insanların krizi nasıl deneyimlediğini anlatmaktadır. Filmlerde krize doğrudan referans olmasa da, karakterlerin hayatına hâkim olan hayal kırıklığı, dengesizlik, şok, kayıp ve acı duygusunun, krizdeki bir toplumun psikolojik durumuna karşılık geldiğini söylemek mümkündür.

Şüphesiz eğer krizden söz ediliyorsa bir tarafta bu krizden fırsat yaratanlar olduğu kadar, çoğunluğun oluşturduğu diğer tarafta krizin yarattığı mağdurlar da söz konusudur. Yunan yeni dalgasının da en çok mağdur karakterlere odaklandığını, hatta ana karakterlerinin genellikle mağdur kişiler olduğunu söylemek yanlış olmayacaktır. Ceza hukukuna göre "suçtan veya haksız fiilden zarara uğrayan kimse" (Türk Hukuk Kurumu, 1991, s. 213) olarak tanımlanan mağdur, Türk Dil Kurumu tarafından ise "haksızlığa uğramış kimse" (1998, s. 1483) şeklinde daha geniş bir çerçevede açıklanmaktadır. Bu noktada herhangi bir kişinin mağdur sayııması için ortada her zaman suç fiili olmasının gerekmediği anlaşılmaktadır. Söz gelimi bireyin cinsel tercihi ya da ırkı nedeniyle toplumdan dışlanması ve ötekileştirilmesi ceza hukukuna göre suç kabul edilmez ancak bu durumun dışlanan kişiyi mağdur ettiği ortadadır. Dolayısıyla mağduriyet kavramının sadece suç oluşturan fiiller kapsamında değerlendirilmesi eksik bir bakış açısı olacaktır. Bu bağlamda Yunan yeni dalgası karakterlerinin istismar, taciz ve tecavüz gibi suçların mağduru olduğu kadar, ataerkinin, ötekileştirmenin, ırkçılığın, işsizliğin ve parasızlığın da mağduru olduğu görülmektedir. Bununla birlikte, Yunan yeni dalga akımını oluşturan filmler hakkında yapılan akademik çalışmaların genellikle 'tuhaf' kavramı çerçevesinde toplumsal cinsiyet, aile, ataerki, kriz, zaman ve mekân konularına odaklandığını, buna karşılık yeni dalga filmlerinin mağduriyet kavramı kapsamında ele alınmadığını saptamak mümkündür.

Bu doğrultuda makalenin amacı; Yunan yeni dalga filmlerinin sıkça ele aldığı konular arasında yer alan aile, aşırı milliyetçilik, ırkçılık, ötekileştirme ve işsizlik konularının ortak noktası olarak mağduriyet kavramını ele almak ve Yunan yeni dalgasının ortak temaları arasında mağduriyet konusunun yer alıp alamayacağını incelemektir. 2000'li yıllara ait genç bir sinema akımı olarak Yunan yeni dalgasına dair 
tartışmaların ve mevcut çalışmaların henüz sınırlı olabileceği göz önüne alındığında, makalenin mağduriyet kavramı üzerinden alana katkıda bulunabileceği düşünülmektedir.

Yunan yeni dalgasının mağduriyete yaklaşımını ve mağdur karakterlerini ele alırken, söz konusu filmleri ülkenin tarihi, kültürel ve ekonomik yapısı ile ilişkili olarak okumak önemlidir. Bu nedenle çalışmada öncelikle Yunan yeni dalgasının genel özellikleri üzerinde durulacak ve yeni dalga filmlerinde krizin mağdur ettiği Yunan toplumunun yansımaları incelenecektir. Ardından yeni dalganın önemli örnekleri arasından seçilen sekiz film, karakterlerinin mağduriyetleri bağlamında değerlendirilecektir. Çalışmada betimsel analiz yöntemi benimsenmiştir. Tematik çerçeve oluşturma, söz konusu çerçeveye göre verilerin işlenmesi, bulguların tanımlanması ve yorumlanması şeklinde dört aşamaya sahip olan betimsel analiz (Altunışık, Coşkun, Yıldırım , \& Bayraktaroğlu, 2010, s. 322), seçilen filmlerin mağduriyet teması çerçevesinde incelenmesi için uygun görülmüştür. Buna göre; Köpekdişi ve Şiddet Güzeli (Miss Violence, 2013, yön. Alexandros Avranas) filmlerinde aile, Plato'nun Akademisi (Akidimia Platonos, 2009, yön. Flippos Tsitos) ve Xenia (2015, yön. Panos H. Koutras) filmlerinde milliyetçilik ve ırkçılık, Kadının Fendi (Strella, 2009, yön. Panos H. Koutras) filminde ötekileştirme, Kuş Yemi Yiyen Oğlan (To Agori Troei To Fagito Tou Pouliou, 2012, yön. Ektoras Lygizas) ve $L$ (2012, yön. Babis Makridis) filmlerinde işsizlik mağduriyet yaratan konular olarak ele alınacak, son olarak Zavallı (Oiktos, 2018, yön. Babis Makridis) filmi ise mağduriyetin cazibesi bağlamında tartışılacak ve mağduriyet kavramının Yunan yeni dalga akımı için tematik bir çerçeve sağlayıp sağlamayacağı araştırılacaktır.

\section{YUNAN YENI DALGA FILMLERININ ÖZELLIKLERI}

Her olumsuz durumun aynı zamanda iyi şeylere vesile olma potansiyeli taşıdığına dair klasik görüşe inanlar için Yunanistan sineması iyi bir örnek olabilir. Krizdeki bir ülke, bu krizden beslenen filmlerin oluşturduğu yeni sinema akımıyla dünya sinemasına önemli bir katkıda bulunmuştur. Ancak kriz ve yeni dalga filmleri arasındaki bağlantıyı doğru kurabilmek için öncelikle dönemin sosyo-kültürel, ekonomik ve politik koşullarını değerlendirmek önemlidir.

Eleni Varmazi, doksanlı yılları Yunanistan için "refah dönemi" olarak niteleyerek, ülkenin iki binli yılları da Atina Olimpiyat Oyunları organizasyonu ile olumlu karşıladığını, ancak hemen ardından şiddetli resesyona girdiğini belirtmektedir (2019, s. 40). Yazara göre kriz nedeniyle uygulanan kemer sıkma 
önlemleri ve Grexit ${ }^{1}$ tehdidi özellikle iyi eğitimli gençleri daha önce görülmemiş işsizlik oranıyla ve düşük maaşlarla yüzleştirmiş, fırsatları sınırlanan yeni neslin finansal olarak ötekileşmesine ve hayal kırıklığına uğramasına neden olmuştur. Dolayısıyla bankalara, mağaza vitrinlerine, arabalara, üniversite kütüphanelerine ve tarihi binalara saldıran protestocuların çoğunluğunu gençlerin oluşturmasının altında söz konusu psiko-sosyal dinamikler aranmalıdır.

Benzer şekilde Maria Chalkou da, 2000'lerdeki Yunan sinemasını konu aldığı yazısında dönemin sosyal, politik ve ekonomik arka planını anlatır ve 2009 yılındaki krize kadar hâkim olan olumlu ortamı bozan negatif gelişmelerden bahseder (2012, s. 256). Yazara göre, yaygın yozlaşma, ekonomik skandallar, terörizm, doksanlardan itibaren hızla ve kontrolsüz biçimde artan göçmen sorununun tetiklediği suç oranları, yabancı düşmanlığı ve ırkçıık, ülkenin doğal kaynaklarını ve yaşayanları etkileyen büyük orman yangınları ve Atina ile diğer büyük kentlerde yıkıma yol açan vandalizm ve sokak ayaklanmaları Yunan toplumunu ciddi bir ekonomik gerileme, derin bir güvensizlik, anksiyete ve hayal kırıklığı ile yüzleştirmiştir.

Söz konusu olumsuz gelişmelerin, pek çok alanı olduğu kadar sinema endüstrisini de etkilemesi kaçınılmazdır. Krizin sinema için olumsuz sonuçlarından biri, pahalı bir sanat formu olan sinemadan devlet desteğinin çekilmesi ya da minimuma indirgenmesi olmuştur. Bu nedenle, bütçe yaratmak için farklı alternatifler arayan ve genellikle ortak yapımlara yönelen sinemacıların işi zorlaşmıştır (Chalkou, 2012, s. 246-249). Ancak bununla birlikte önemli bir fırsata da kavuştuklarını söylemek yanlış olmayacaktır. Bu fırsat, devlet desteğine olan bağımlılı̆ın ortadan kalkmasıyla yönetmenin biçimsel ve içerik açısından bağımsızlaşmasıdır. Dolayısıyla Yunan yeni dalgasının geleneksel olmayan anlatılara ve yenilikçi biçime dayalı filmler ortaya koyması biraz da söz konusu ekonomik durumla ilgilidir.

Bununla birlikte filmlere bakıldığında ekonomik krizle ilgili direkt bir mesaj ya da gönderme bulmak pek olası değildir. Ancak krizin yarattığı karamsar ve umutsuz ortam hikâyelerin arka planında kendisini hissettirmektedir. Attenberg'de hissedilen küçük burjuva bunalımı, L'deki işini kaybeden isimsiz karakterin absürt çabası, Kuş Yemi Yiyen Oğlan'ın açlı̆̆ı ve yalnızlığı doğrudan ekonomik krizle ilgili olmasa da krizin mağdur ettiği insanların ruh halini yansıtmaktadır. Attenberg'de hasta babasının Marina'ya

\footnotetext{
1 "Greek exit"in kısaltması olan kelime, Yunanistan'ın Avrupa Birliği üye ülkelerinin ortak para birimi olan euro'dan ayrılarak Yunan Drahmisi'ne geri dönmesi anlamına gelmektedir.
} 
söyledikleri, filmlere sinmiş olan dönemin hayal kırıklığını gösteren belki de en açık ifadedir. Ölümü bekleyen baba öz eleştiride bulunarak "sanayi devrimini es geçmiş bir ülkenin burjuva kibri"nden söz eder önce ve sonra ekler: "Ağılların üzerine sanayileşmiş bir ülke kurduk". Babanın sözleri, artık tarihin sahnesinden inmek üzere olan ve yeni nesle kayıplardan ve yenilgiden başka bir şey bırakmadığını düşünen önceki jenerasyonun günah çıkarması gibidir adeta: "20. yüzyılı boykot ediyorum. Fazla büyütüldü, onu bıraktığım için de hiç üzülmüyorum. Ihtiyar bir ateistim. Aydınlanma sonrasının zehirli bir modernizm kalıntısıyım. Seni yeni yüzyılın ellerine hiçbir şey öğretmeden bırakıp gidiyorum şimdi". Yönetmenin karaktere söylettiği bu sözler, yeni dalganın geçmişle bağı koparma arzusunun haklı çıkarılmasına da yöneliktir.

Yunan yeni dalgasının geçmişten kopma isteğinin iki bileşeni bulunmaktadır. İlk olarak, antik döneme kadar uzanan görkemli bir tarih üzerine inşa edilen Yunan kimliğinin reddi söz konusudur. Büyük tarihsel olaylara tanıklık etmiş, altmışlı yılların devrimci ruhunu taşıdığını iddia eden, askeri cunta karşıtı hareketlerin mirasçısı eski jenerasyonun politik ve kültürel değerleri yeni neslin uzağına düşmüştür. Bu nedenle Steve Rose'a göre yeni dalga filmleri, geçmişin tiranlığından acı çeken yeni nesil Yunanların dolaysız yansımasını taşımaktadır (2011). Marina'nın babasının itiraf ettiği gibi eski, yeniye güvenilir kurumlar, istikrara ve refaha dayalı bir toplum bırakamamıştır ve belki de bu yüzden yeni neslin yapması gereken kökleriyle bağını kesmektir.

Yunan yeni dalgasının geçmişten kopuşunun ikinci bileşeni ise, daha önceki auteurlerin sinema anlayışından farklı, daha çağdaş ve çeşitlilik barındıran filmler üretilmesine doğru yaşanan değişimdir. Çoğu yurtdışında eğitim görmüş, reklam sektöründe deneyim kazanmış, uluslararası festival çevreleriyle bağlantıları olan ve yeni teknolojik gelişmeleri yakından takip eden genç yönetmenlerin filmleri, biçim ve içerik açısından öncüllerinden farklıdır. Onlarınki, geçmişe yönelik nostaljik bir bakışın ve tarihsel travmaların yerine şimdiye odaklanan ve bugünün sorunlarını anlatan filmlerdir. Sonuç olarak, Yunan yeni dalgasının geçmişten kopuşunun ortak noktasında, eski pratiklerden, geleneklerden ve ideolojilerden özgürleşerek tamamen bağımsız ve yeni bir sinema anlayışı oluşturma idealinin bulunduğunu söylemek mümkündür.

Bununla birlikte Yunan sinemacılar, uluslararası eleştirmenlerin nitelemelerinin aksine yeni bir sinema hareketi başlattıklarını reddederek, filmlerinin bireyselliğinde ısrar etmektedir. Akımın 
öncülerinden kabul edilen Yorgos Lanthimos'un sözleriyle "Ortada bir hareket, ortak bir film dili yok"tur (akt. Chaplinsky, 2012). Bununla birlikte söz konusu filmlere bakıldığında belli bir akıma dâhil edilmelerine neden olabilecek bazı ortak karakteristiklere sahip oldukları görülmektedir. Başka bir ifadeyle Yunan yeni dalgasını oluşturan filmlerin tek belirleyici noktası filmlere sinmiş olan tuhaflık duygusu değildir. Estetik ve tematik açıdan aralarında pek çok ortaklık saptanabilir. Bu kapsamda anılan filmlerin genel olarak aile, iktidar, ataerki, toplumsal cinsiyet, kimlik, beden, şiddet ve kayıp gibi temaların etrafında döndüğü görülmektedir.

Yunan yeni dalgasının karakteristik özelliklerine sinematografisinden yola çıkarak bakıldığında ilk dikkati çeken minimal film dili kullanımıdır. Hareketsiz ve sabit kamera, uzun çekimler, yavaş kurgu, sessizlik, mekanik ve ifadesiz oyunculuk yeni dalga filmlerinin çoğunda karşımıza çıkmaktadır (Poupou, 2018, s. 305). Tüm bu özellikler, ana akım sinemanın izleyiciyi filmin içine çekebilmek için tercih ettiği tekniklerin zıddı olarak aslında yabancılaştırmaya yöneliktir. Böylece film seyirciden duygusal değil, zihinsel katılım bekler.

Filmlerdeki başka bir ortak özellik olan donuk, ruhsuz ve neredeyse robotumsu denilebilecek oyunculuk tarzına ayrıca değinmek gerekmektedir. Karakterlerin hissettiği korku, üzüntü, şaşkınlık veya öfke gibi yoğun duyguları yüz ifadelerinden ya da beden dillerinden okumak pek mümkün değildir. Kimi zaman teatral bir yöne kayarak doğalıktan uzaklaşan bu oyunculuk biçimi, yaşadıkları karşısında karakterlerin kayıtsız mı yoksa sadece şoka mı girmiş olduğu konusunda izleyicinin kafasını karıştırır. Filmlere absürtlük duygusu katan biraz da bu kafa karışıklığıdır. Ancak, bazen abartıı ve ağdalı cümleler, şiirler ya da şarkılarla kendisini anlatmaya çalışan, bazen de konuşmak yerine dans ederek ya da garip bedensel hareketler yaparak duygularını ifade eden bu 'tuhaf' karakterleri, ekonomik krizin mağdur ettiği Yunan halkının yansıması olarak okumak doğru olacaktır.

\section{YUNAN YENI DALGA FILMLERININ MAĞDUR KARAKTERLERI}

Eleştirmenlerin Yunan sinemasında yeni bir akımın doğduğunu iddia etmelerine neden olan en önemli karakteristik özellikler filmlerin içeriğinde karşımıza çıkmaktadır. Filmlerde genellikle geleneksel anlatı yapısı yoktur. Çoğu zaman nedensel ve doğrusal bir öyküleme görülmez, buna karşılık deneysel ve alegorik anlatım öne çıkmaktadır. Özdeşleşmenin mümkün olmadığı karakterler, absürt ve garip mizah anlayışı ile belirsiz bir uzam da bunlara ek olarak söylenebilir. Bu noktada bir başka ortak karakteristikten 
bahsetmek daha anlamlı olacaktır. Yunan yeni dalgasının etrafında döndüğü konuların özünde mağduriyet teması yer almaktadır. Dolayısıyla Yunan yeni dalgasının ortak karakteristikleri üzerine çoğu yazarın hemfikir olduğu başlıklara mağdur karakterleri de eklemek gerekmektedir. Çünkü bu filmlerdeki karakterler genellikle mağdur konumundadır. Babalarının taciz ve tecavüz ettiği çocuklar, cinsel tercihi nedeniyle toplumsal baskı gören eşcinseller, ırkçı şiddete uğrayan ve dışlanan gençler ve işsizlik yüzünden sıkıntı yaşayan erkekler ataerkil ailenin, geleneksel ve milliyetçi Yunan toplumunun mağdur ettiği bireyler olarak, bahsedilen filmlerin ana karakterleri şeklinde karşımıza çıkmaktadır.

\section{Yunan Yeni Dalga Filmlerinde Aile ve Mağduriyet}

Varmazi, Yunan yeni dalgasında tekrarlayan meseleler olarak aile ve kimlik kaygılarına işaret eder ve bunların keskinlik, ironi, gizemden arındırma ve soğuk eleştiri aracılığıyla yansıtııı̆ı̆ını belirtir (2019, s. 42). Gerçekten de aile, Yunan yeni dalgasının en çok meşgul olduğu konuların başında yer almaktadır. Bu noktada, yönetmen Athina Tsangari'nin Yunan yeni dalgasının özellikle aile meselesiyle uğraşması hakkındaki yorumu aydınlatıcıdır: "Yunan yeni jenerasyonunu birleştiren şey, aileye dair duydukları kaygıdır (...) Bu bir yunan takıntısıdır. Politika ve ekonomimizin böyle bir belada olmasının nedeni de aile gibi yürütülmesidir" ( akt. Rose, 2011).

Buna göre ailenin, çoğu Yunan yeni dalga filminde üyeleri için mağduriyet alanı yaratan bir kurum şeklinde sunulduğu görülmektedir. Oysaki aynı kurum, Marios Psaras'ın sözleriyle (2016, s. 8) "estetik bir kategori olarak Yunan olma statüsünü muhtemelen en iyi şekilde özetleyen 'Anayurt, Din, Aile' sloganının" en önemli sacayaklarından birini oluşturmaktadır. Slogandaki anayurt, görkemli antik Yunan geçmişinden başlayarak modern döneme kadar uzanan ve milliyetçi değerlerle idealize edilen Yunan kimliğine göndermek yapmaktadır. Din, Yunanistan'da toplumsal ve siyasal hayat üzerinde her zaman büyük etkisi olduğu bilinen Ortodoks Kilisesi'nin temsil ettiği inanç sistemini işaret etmektedir. Aile ise, konvansiyonelliğin biçimlendirdiği ve ataerkil ideolojinin vücut bulduğu, "geleneksel inançları ve değerleri tehdit eden ahlaksız feminist söyleme karşı olduğu kadar, Marksist ve sosyalist düşüncelerin yayılmasına karşı da güvenlik duvarı olarak görevlendirilen" (Psaras, 2016, s. 9) ideal bir kurum olarak sloganı tamamlamaktadır.

Yunan tuhaf dalgasının geçmişten uzaklaşma eğilimi ve bununla bağlantılı olarak 'Yunan olma' konusunun güncel gerçeklikle ilişkili ele alındığı hatırlandığında, sloganı oluşturan 'anayurt, din ve aile' 
kavramlarının da yapı bozumuna uğratıldığı görülmektedir. Yunan yeni dalgası yönetmenleri milliyetçiliği, ataerkil aileyi, tutucu değerleri ve bunları üreten resmi söylemi eleştirerek, bunları ırkçılık, ötekileştirme, taciz, tecavüz ve ensest kapsamında ele almaktadır. Başka bir deyişle, geçmişin kurucu değerleri, şimdinin mağduriyet kaynakları haline gelmiştir.

Bu doğrultuda, yeni dalga filmlerinde karşılaşılan ailelerin, Yunan toplumunu yansıtan birer mikro evren olarak ele alındığı görülür. Bu filmlerdeki işlevsiz aileler, toplumdaki iktidar ilişkilerini, şiddet ve toplumsal cinsiyet dinamiklerini temsil etmektedir. Özellikle Köpek Dişive Şiddet Güzeli gibi filmler, aile içi ilişkilerde saklı olan şiddet ve zulme, aşırı korumacı ve suiistimalci ailelere odaklanan anlatıları ile yeni dalganın aileye bakışını açıkça göstermektedir.

Yunan yeni dalgasının ilk örnekleri arasında yer alan Köpek Dişi rahatsız edici alegorik anlatımıyla sistem eleştirisi yapan, izleyiciyi yabancılaştırarak sorgulamaya yönlendiren önemli bir filmdir. Lydia Papadimitriou, filmin yönetmeni Lanthimos'un Köpek Dişi filminde dönemin sosyo-politik gerçekliğine doğrudan referans vermekten kaçınarak, yarattığı kapalı dünya ile gizemli ve alegorik bir kriz tasvir ettiğini belirtir (2014, s. 2). Film, anne-baba ve ergenlik çağındaki ikisi kız, biri erkek üç çocuktan oluşan bir aileyi konu alır. Nerede olduğu konusunda bilgi verilmeyen, muhtemelen şehir dışındaki izole bir evde yaşayan bu aile, dış dünyadan tamamen kopuk, babanın koyduğu keyfi kurallara göre yaşamaktadır. Aile içinde çocuklara verilen eğitim ise son derece yanıltıcıdır. Babanın kararları ve otoritesi doğrultusunda inşa edilen bu çarpık dünyada, dilin manipüle edilmesi ile deniz, otoyol, seyahat, telefon gibi özgürlüğü ve iletişimi çağrıştıran kelimeler bambaşka şeyleri karşılar hale gelmiş, evin yüksek duvarları arkasındaki dünya, ayak bile basılmaması gereken, insan için sözde en tehlikeli yaratık olan kedilerin cirit attığı bir vahşi mekâna dönüşmüştür. Yine bizzat baba tarafından teşvik edilen ensest ise, sadece erkek kardeşin cinsel ihtiyacını karşılamaya yöneliktir.

Görüldüğü üzere Lanthimos kurduğu rahatsız edici evrende alışılmış aile temsillerini ters yüz ederek alegorik bir şekilde sistem eleştirisi yapmaktadır. Buna göre "Toplumsal iktidarı; kuralcı, baskıcı ve yanılsamalar yaratıı baba figürüyle görünürleştiren film, günümüz insanının sistem içerisindeki sıkışmışlığını ise çocuklar vasıtasıyla temsil etmektedir" (Bilis, 2018, s. 62). Baba figürü; devletin yasasının, Tanrı'nın buyruğunu ileten dini kurumların, kadını ikincil konuma yerleştiren ataerkil otoritenin, kısacası her türlü toplumsal erkin uygulayıcısı ve aynı zamanda kural koyucusu ve cezalandırıcısı 
konumundadır. İsimleri bile olmayan çocuklar ise, sistemin ezdiği mağdurlar olarak karşımıza çıkmaktadır. Bu doğrultuda, koruyuculuk kisvesi altında hakları çiğnenen, yanlış yönlendirilen, istismar edilen baskıcı rejimlerin yetiştirdiği nesillerin alegorisi şeklinde okunmaları gerekir.

Filmin mağdur karakterleri arasına evin çocuklarının yanı sıra, erkek kardeşin cinsel ihtiyacını karşılaması için baba tarafından düzenli olarak eve getirilen kadın güvenlik görevlisi Christina'nın da eklenmesi önemlidir. Filmde ismi bilinen tek karakter olan Christina'nın para karşılığı bu işi kabul etmiş olması öncelikle ekonomik krizin mağdurlarından biri olduğunu düşündürmektedir. Kız kardeşlerden birine film getirdiği ve dolayısıyla evdeki sözde dengeyi bozma tehdidi taşıdığı ortaya çıtığında ise genç kadın, baba karakteri tarafından şiddet görür. Buna göre, Christina'nın mağduriyetinin ekonomik ve eril şiddete dayanan çift taraflı boyuta sahip olduğu görülmektedir.

Ana akım sinemada sıklıkla karşılaşılan, ailesini korumak ve geçindirmek için her türlü fedakârlı̆̆ı yapan, şefkatli ve korumacı baba temsillerine karşılık Yunan yeni dalgasında suiistimalin, eril şiddetin ve baskının baş uygulayıcısı haline gelen baba figürü Şiddet Güzelınnde bir kez daha karşımıza çıkmaktadır. Film, sinema tarihinin en çarpıcı giriş sahnelerinden biriyle, 11 yaşına giren Angeliki'nin doğum günü partisinde, ailesiyle şarkılar eşliğinde kutlama yaparken, kameraya gülümseyip kendisini pencereden aşağı bırakmasıyla başlar. Buradaki aile de baba, anne, biri yetişkin, diğeri lise çağında iki kızları ve yetişkin kızları Eleni'nin üç çocuğundan oluşmaktadır. Angeliki, Eleni'nin kızıdır. Baba Philippos'un katı kuralları altında yaşayan aile, Köpek Diş̧’ndeki absürt yasaklar kadar olmasa da sıkı bir denetime tabidir. Söz gelimi hiçbir aile üyesi odasının kapısını kilitleyemez, hafta sonu nereye gidileceği konusunda baba dışında kimsenin söz hakkı yoktur ve en ufak bir hata fiziksel şiddetle cezalandırılmaktadır. Olay örgüsü ilerledikçe Philippos'un Eleni ve diğer kızı Mytro'yu başka erkeklere pazarladığını ve kendisinin de kızlarına tecavüz ettiğini görürüz. Angeliki, bunlara maruz kalmamak için ölümü seçmiştir. Philippos en sonunda en küçük kız torununu da yaşlı bir erkeğe pazarlayınca, eşi tarafından öldürülür.

Aileyi, şiddetin her türlüsünün yoğun biçimde yaşandığı ancak buna karşılık görünmez olduğu bir yapı olarak tasvir eden film, resmi kurumların da kayıtsızlığına dikkat çekmektedir. Angeliki'nin intiharını sorgulayan görevliler, Eleni'nin üç çocuğunun da babalarının belli olmadığını öğrenir ancak aile içi taciz ve istismardan şüphelenmez. Evde despot bir tiran gibi davranan Philippos başkalarına karşı nazik bir adama dönüşmektedir. İşsizdir ve sadece kızlarını pazarlayarak değil, torunları için devletten sosyal 
yardım da alarak geçinmektedir. Üstelik Eleni tekrar hamiledir ve baba, doğacak olan bebekle birlikte maddi ve manevi sömürüsünü sürdürmeye devam edecektir. Dolayısıyla yeni nesil için umutlu bir gelecekten söz etmek mümkün görünmemektedir. Finalde karısının Philoppos'u öldürmesi de iyimser bir tablo vadetmez; son sahnede anne, karşısında sıraya dizilmiş duran iki kızına ve torunlarına yüzünde memnun bir ifadeyle bakar ve Eleni'ye kapıyı kilitlemesini söyler. Buna göre iktidar ortadan kalkmamış, sadece el değiştirmiştir. Filmin kapanış sahnesi şiddetin, tacizin ve tecavüzün mağdurları için değişen bir şey olmayacağını ima etmektedir.

Köpek Dişi ve Şiddet Güzelınde ailenin olumsuz temsiline paralel şekilde evin de, karşılıklı sevgi, şefkat ve anlayışın üretildiği bir yuva değil, içinde yaşayanlar için baskı ve denetimin en koyu halini üreten bir 'kapan-mekân' haline geldiği görülmektedir. Anna Poupou'ya göre Yunan yeni dalga filmlerinin en güçlü düzenlemelerinden biri kuşatıımış ve sınırlandırılmış uzamdır (2018, s. 298). Yazar bu temanın, yeni nesil ile askeri diktatörlük döneminde ortaya çıkan ve hapishane ya da sürgün gibi mekânları alegorik yollarla anlatan yeni Yunan sineması arasında bağlantı kurulmasına hizmet ettiğine vurgu yapar. Buna göre yakınlığın ve içinde yaşayanlar için koruyucu bir kabuğun simgesi olan ev figürü, kısıtlayıcı, kapalı, domestik şiddetin yeniden üretildiği ve buna karşılık görünmez hale geldiği tekinsiz bir uzam olarak temsil edilmektedir. Böyle bir mekânda özgür olabilmek ise ancak, Angeliki'nin bilinçli olarak tercih ettiği, Köpek Dişı'ndeki büyük kızın ise kaçıp saklandığı araba bagajında muhtemelen tanıştığı ölümle mümkün olabilmektedir.

\section{Yunan Yeni Dalga Filmlerinde Milliyetçilik, Ötekileştirme ve Mağduriyet}

Yunan yeni dalgasının mağdur karakterleri sadece ataerkil ailenin üyeleri olarak karşımıza çıkmaz. Yunan kimliğinin oluşturucu sloganındaki anayurt kavramının barındırdığı milliyetçilik de, ırkçılığın ve yabancı korkusunun mağdurlarını yaratmaktadır. Yunan toplumunun yabancıya bakışını mizahi ama eleştirel bir açıdan ele alan Plato'nun Akademisi, 'bir adam, her zaman en çok nefret ettiği şey olduğunu keşfettiğinde ne yapar' sorusunu ırk üzerinden tartışmaya açmaktadır. Filmin ana karakteri Stavros, üç yakın arkadaşıyla birlikte ülkedeki tüm yabancılara ama en çok da Arnavutlar'a karşı açık bir nefret duygusu içindedir. Yabancı düşmanlığının canlı birer örneği olan dört arkadaş, her gün Stravros'un dükkânının önünde boş boş oturup aynı sokakta işyeri açma hazırlığı yapan Çinlileri izlemektedir. Bu esnada çok yaygın bir önyargıyı da yeniden üretmekten kaçınmazlar; onlara göre tüm Çinliler birbirinin 
aynısıdır, dolayısıyla karşı tarafta tam olarak kaç kişinin çalıştığını saymak mümkün değildir. Stavros ve arkadaşlarının nefretinden en büyük payı ise Arnavutlar almaktadır. İçlerinden biri Patriot (Vatansever) isimli köpeğini sadece Arnavutlara havlayacak şekilde eğittiğini iddia etmekte; dörtlü, yoldan geçen Arnavut boyacıya sataşmaktadır. Ancak Stavros, aynı boyacının öz abisi olduğu iddiasıyla şaşıracak, bu da yetmezmiş gibi yaşlı annesinin birden bire Arnavutça konuşmaya başlamasıyla şoka girecektir.

Stavros'un aslında Arnavut olduğunu öğrenmesi kendisi için fazlasıyla travmatik olur. Çünkü bir yanda dilini ve kültürünü bilmediği, uzun yıllardır nefret ettiği bir kimliği benimsemesi kolay görünmemektedir. Diğer yanda ise arkadaşları tarafından dışlanmış ve Yunanistan ile Arnavutluk arasındaki maçta Yunanistan lehine slogan atması bile uygun bulunmamıştır. "Asla Yunan olamayacaksın, Arnavut" (You Will Never Be Greek, Albanian) şeklindeki söz konusu slogan, 2004 yılındaki UEFA Avrupa Futbol Şampiyonası'da Yunan zaferini kutlayan taraftarların kullandığı gerçek slogana göndermedir. Stavros yüksek sesle bu sözleri tekrar ettikçe, artık Yunan kimliğine de ait olmadığını fark eder. Unutkanlık atakları yaşayan annesi de Stavros'un kimlik krizini yineler gibidir: "Sen kimsin?" diye sorar oğluna. Kimdir Stavros? İnsan uzun yıllardır üzerinde yaşadığı, kültürünü, tarihini benimsediği topraklara mı aittir; yoksa kan ile bağı olduğu, genetik kodlarını taşıdığı kimliği mi daha önemlidir? Film tüm bu soruları düşünmemizi ister ve ırkçı düşüncenin aslında toplumsal ve kültürel olarak yapılandırıldığına dikkat çeker. Ötekileştirilen ve bu nedenle pek çok konuda mağduriyet yaşayan etnik gruplara karşı duyulan nefret, korku ve kin gibi duyguların büyük ölçüde kültürel üretimlerden kaynaklandığını vurgular.

Benzer vurgu, 2014 tarihli Xenia'da da karşımıza çıkmaktadır. Panos H. Koutras tarafından yönetilen film, Arnavut annelerinin ölümünün ardından Yunan babalarını bulmak ve şarkı yarışması Yunan Star'a katılmak için yollara düşen iki erkek kardeşin, Dany ve Ody'nin öyküsünü konu alır. Babalarını arama nedenleri Yunan vatandaşlı̆ına geçmek istemeleridir. Ancak iki kardeş yolculukları boyunca, göçmen kimlikleri dolayısıyla olduğu kadar, Dany'nin eşcinsel olması nedeniyle de çoğu zaman dışlanır ve hem ırkçı nefrete hem de homofobik şiddete maruz kalır. Film boyunca Yunanların, farklı milletten kişilere yönelik kötü muameleleri gösterilmektedir. Sözgelimi iki kardeş Atina'da yolda yürürken birkaç Yunan'ın "Yunanistan'a gelmişsiniz, Yunanca konuşamıyorsunuz" diyerek Hintlilere sataştığına tanık olur. Bir başka sahnede Dany, gay barda tanıştığı Mustafa isimli gençle sokakta yürürken, aynı sokakta dükkân sahibi Araplar faşist bir grubun saldırısına uğrar. "Elimizde ateşler ve baltalar, öldürülecek 
Araplar! Yunanistan Yunanlarındır, Hıristiyanlarındır" sloganıyla dükkânlara saldıran grup, başörtülü bir kadının da örtüsünü sıyırır. Bu sırada olay yerine gelen polisin, duruma müdahale etmediği gibi onları durdurmak isteyen Dany'yi gözaltına alması resmi otoritelerin faşist şiddete göz yumduğunu gösterir niteliktedir.

Sadece etnik kökenleri değil Dany'nin cinsel kimliği de sorun yaşamalarına neden olmaktadır. Dany, kendisini hem eşcinsel hem de Arnavut olduğu için tartaklayan gençlerden birini yaralayınca iki kardeşin yolculuğu polisten kaçış öyküsüne evrilir. Bu noktada, Antik Yunan'da 'kutsal misafirperverlik kuralı' anlamına gelen (Smith, 1870, s. 1288) ve kardeşlerin saklandığı terk edilmiş, yıkık dökük otelin ismi olan Xenia'nın filme adını vermesi ironiktir. Söz konusu kural, ev sahibinin, hiç tanımadığı bir misafiri bile en iyi şekilde ağırlamasını gerektirmektedir ve özellikle mitolojik öykülerde sıklıkla karşımıza çıkan bir temadır. Bu öykülerin en bilinenlerinden biri ise ithaka Kralı Odysseus'a aittir ve filmin ana karakterlerinden Ody, aslında Odysseas'ın kısaltmasıdır. Hatırlanacağı üzere, Homeros'un Odyssea Destanı, Odysseus'un Truva Savaşı́nın ardından evine dönmesi sırasında yaşadığı on yıllık macerayı anlatmaktadır. Cesaret, kahramanlık, sadakat gibi temalar üzerinden işleyen Odysseus'un hikâyesinde xenia'nın, yani kutsal misafirperverlik kuralının özel bir önemi olduğu vurgulanmalıdır. Odysseus ve adamları gittikleri farklı krallıklarda bu kural gereği son derece iyi ağıllanır, örneğin kim oldukları bile sorulmadan önce karınları doyurulur, banyoları hazırlanır. Dolayısıyla xenia, Odysseus ve adamlarının hayatta kalmasını büyük ölçüde kolaylaştırmıştır. Ancak Odysseus Ithaka'ya döndüğünde, bizzat kendisi bu kuralı çiğner. Eşi Penelope'ye talip olarak gelmiş ve bu nedenle evinde konaklayan yüzlerce misafiri oğlu Telemakhos ile birlikte katleder (Homeros, 2008). Bu bağlamda filme geri döndüğümüzde, Odysseus'un ihlal ettiği bu kuralın, yani yabancılara gösterilen nazik ağırlamanın, günümüzde de Yunan milliyetçiliği nedeniyle tedavülden kalktığı, tıpkı filmdeki otel gibi terk edildiği ima edilmektedir.

Bahsedilen iki örneğin de işaret ettiği üzere Yunan yeni dalgasında tekrarlanan bir diğer meselenin de kimlik krizi ve buna bağlı olarak yeni kimlik arayışı çerçevesinde şekillendiği görülmektedir. Ody, kendisine Arnavutluk'a gitmek isteyip istemeyeceğini soran Maria'ya orada da yabancı olarak karşılanacağını söyler. İki tarafın da ötekileştirdiği, iki tarafa da ait olamayan bir yabancıdır. Ama aynı zamanda "her yer evimiz" der Ody. Yaşadığı kimlik krizine iyimser bir yaklaşımdır bu, ancak ne kadar aksini düşünmek istese de öteki olduğu gittiği her yerde ona hissettirilecektir. Martha Nochimson'ın belirttiği gibi "Ulusal sinema kültürüne ait filmlerin seyirci ve ana karakterler arasında kurduğu ilişki, bireysel 
kimliğin belli bir ulusal topluluğun içinde inşa edilmesini içerir" (2012, s. 18). Ancak Plato'nun Akademisive Xenia gibi yeni dalga örneklerinde 'çağdaş ve çok kültürlü Yunan imgesi'ne karşılık, yabancı korkusuna, ırkçılığa ve milliyetçiliğe dayalı bir ülke temsili karşımıza çıkmaktadır.

Yunan milliyetçiliğinin olumsuz sonuçları arasında gösterilen ırkçılık ve yabancı korkusunun mağdurlarından başka toplumda ötekileştirilen bir diğer gruptan, eşcinsellerden de bahsetmek gerekmektedir. Toplumsal cinsiyete dair farkındalıkların arttığı günümüzde dahi, eşcinsellerin ve trans bireylerin dışlandığı, nefret söylemine maruz kaldığı ve hatta şiddete uğradığı bilinmektedir. Ana akım sinemada da söz konusu ötekileştirmenin devam ettiği görülmekle birlikte, özellikle iki binli yıllardan itibaren olumlu LGBT temsilleri de karşımıza çıkmaktadır. Yunan yeni dalgası da resmi toplumsal cinsiyet politikalarının mağdur ettiği bireylerin öykülerini anlatmaktan kaçınmamıştır.

Panos H. Koutras'ın Xenia'dan altı yıl önce çektiği Kadının Fendi, cinsel kimlik, transseksüellik, ensest ve aile konularını cesur denebilecek bir açıdan anlatmaktadır. Film, oğluyla cinsel yakınlık kuran erkek yeğenini öldürdüğü için on dört yıldır hapiste olan Yorgos'un tahliye edilmesiyle başlar. Yorgos, hapisteyken izini kaybettiği oğlunu aramaktadır. Bu esnada, kaldığı otelde tanıştığı Strella isimli bir transseksüelle ilişkiye başlar. Olay örgüsü ilerledikçe Strella'nın, aslında Yorgos'un oğlu olduğu ve bilerek babasıyla ilişki kurduğu anlaşılır. Strella'nın diğer trans arkadaşlarının yan öyküleriyle zenginleşen filmin sonunda Yorgos ve Strella arasındaki çatışma tatıya bağlanır ve film, ikilinin Strella'nın arkadaşlarıyla birlikte yeni yıl kutlamaları yaptıkları sahneyle biter. Bu mutlu son, Yunan yeni dalgasının neredeyse bütün toplumlarda katı bir tabu olan ensest yasağına karşı çıkmasıdır. Yorgos ve Strella arasındaki aşk ve ikisinin sevgili olarak beraber yaşamayı kabul etmesi 'ideal Yunan aile miti'ne de açık bir saldırı olarak okunmalıdır. Filmde ayrıca, özünde Yunan aile trajedisi olarak nitelendirilebilecek Oedipus'un hikâyesinden izler bulunur. Kaynağını bu öyküden alan Oedipus kompleksi filmde, ters (ya da olumsuz) formuyla karşımıza çıkmaktadır. Sigmund Freud, kavrama sonradan eklediği ters Oedipus kompleksiyle, çocuğun babayla evlenme ve rakip olarak görülen anneyi öldürme isteğine işaret etmektedir (2011, s. 92-93). Buna göre, erkek çocuğun rakibi gördüğü babayla özdeşlemesini ifade eden düz Oedipus kompleksinden farklı olarak ters komplekste, erkek çocuk babasına karşı hissettiği kadınsı sevgi nedeniyle erkeksi özdeşleşmeden vazgeçerek anneyle özdeşleşmeye yönelmektedir. Çocuğun ruhsal çiftcinselliği ile ilişkilendirilen Oedipus kompleksinin basit ve ters formları arasındaki çatışma, bireyin 
cinsel kimliğinin belirlenmesinde önemli görülmektedir. Bu doğrultuda Strella'nın çocukken ters Oedipus kompleksi doğrultusunda psikoseksüel gelişimini sürdürdüğü anlaşılmaktadır.

Öte yandan filmde, eşcinselliğe dair toplumdaki genel hoşgörüsüzlüğü içselleştirerek, dışlanmamak için cinayet bile işleyen Yorgos'un, kendi gerçek cinsel eğilimiyle yüzleşmesi ve barışması söz konusudur. Filmin sonunda toplumun dayattığı 'maço ve eril kimliğini' bir yana bırakarak, eşcinsel kimliğini bastırmaktan vazgeçmektedir. Filme ismini veren Strella ve arkadaş çevresindeki diğer transseksüellerin de toplumun marjinal bireyleri olarak değil, her biri ayrı fantezi, korku ve arzulara sahip gerçek karakterler şeklinde temsil edildiği görülmektedir. Toplumdan dışlanan, ayıplanan, ötekileştirilen ve bu nedenle mağdur konumunda olduklarını söyleyebileceğimiz queer bireyler, Yunan yeni dalgası içinde kendisine olumlu yer bulmuştur.

\section{Yunan Yeni Dalga Filmlerinde İşsizlik ve Mağduriyet}

Belirtildiği üzere ekonomik kriz, yeni dalga filmlerde doğrudan bir şekilde yer almamaktadır. Bununla birlikte Yunan yeni dalgasında işsizlik ve parasızlı̆ın mağdur ettiği karakterlere rastlamak mümkündür. Bu örneklerden ilki Kuş Yemi Yiyen Oğlan filminde karşımıza çıkmaktadır. Filmin neredeyse yarısına kadar adını öğrenemediğimiz ana karakter en fazla yirmili yaşlarında olduğunu tahmin edebileceğimiz genç bir erkektir. Kanaryasıyla birlikte yalnız yaşamaktadır. Filmin henüz başında genç karakterin oldukça güzel bir sese sahip olduğunu ve müzik konusundaki yeteneğini fark ederiz, ancak bir türlü iş bulamamakta ve para kazanamamaktadır. Kendisine yiyecek bile alamaz, bu nedenle kimi zaman çöpe atılmış bir poşetten çıkanları, kimi zaman bahçeye düşen meyveleri, kimi zaman da kanaryasının yemini yediği görülmektedir. Knut Hamsun'un Açlıkisimli romanının serbest uyarlaması olan film, karnını doyuramamanın insanı nasıl bir çaresizlik içinde bıraktığını ajitasyon sınııını aşmadan anlatmaktadır. İsimsiz delikanlının film boyunca açlığını bastırmak için yedikleri (kaşık dolusu toz şekerden sperme kadar) bazen irrite edici olsa da kendisini ve kanaryasını beslemek için gösterdiği çaba, yürek burkucu olduğu kadar anlaşılırdır.

Film boyunca ana karakterin tek sınavı açlık değildir. Faturaları ödeyemediği için evde sular kesilir, temizlenmek için duş alması mümkün olmaz. İş bulamaz ve bir süre sonra evden de atılır. Yanından ayırmadığı kanaryası ile boş bir inşaata sığınır. Kendisine ve kanaryasına yiyecek bir şeyler alabilmek için kalan son eşyalarını satmaya çalışır ancak bilgisayarını çok düşük bir rakama satmaya gönlü razı olmaz. 
Satmaya kıyamadığı bilgisayarını bir evin kapısına bırakıp kaçtığında hem adının Yorgos olduğunu hem de bir ailesi olduğunu öğreniriz. Madem Yorgos kimsesiz biri değildir o halde neden ailesinden yardım istemez? Bu sorunun cevabını Yunan yeni dalgasının geçmişle bağını koparma arzusunda aramak doğru olacaktır. Yorgos'un içler acısı hali, genç nesillere sahip olmaları için öğütlenen yetenek, çok çalışma ve azim gibi kapitalist değerlerin içi boş laflardan ibaret olduğunu örnekler niteliktedir.

Özellikle batı toplumlarında egemen olan neo-liberalizmin sosyal adalet ve özgürlük söylemi, sistemin adaletsizliklerini ve mağdurlarını görünmez hale getirmekte ve ana akım anlatılar da çalışkan ve hırslı karakterlerin başarı öyküleriyle egemen söylemi desteklemektedir. Bu hikâyelerde mağdurlar bile eninde sonunda şeytanın bacağını kırmaktadır. Kıramayanların sorununu ise kusurlu ve yetersiz kişiliklerinde, 'kötü' aile yapılarında ya da zayıf iradelerinde aramak gerekmektedir. Başka bir ifadeyle, kişinin iyi bir iş sahibi olamaması, kariyerinde ilerleyememesi ve maddi sıkıntı çekmesi tamamen kişisel bir problem olarak sunulur. Böylece fakirlik ve işsizlik toplumsal bağlamından koparılır; mağduriyetlerin kaynağı olarak başarısız ekonomi politikaları ve adaletsiz yönetim anlayışı değil, kişinin kendisi işaret edilir.

Kuş Yemi Yiyen Oğlan'da ise Yorgos ne irade yoksunu ve beceriksiz bir genç, ne de azmi ve şansı sayesinde kötü talihini yenecek bir kahramandır. O, Yunan ekonomik krizinin yıkıcı ve yıpratıcı sonuçlarını tecrübe eden neslin temsilcisi, Psaras'ın tabiriyle, "insanlığın sosyal, politik ve kültürel matrislerini düzenleyen normatif güçlerden gönüllü olarak ilişkisini koparmış insan atığıdır" (2016, s. 192). Yazarın kast ettiği normatif güçler ise Yunan toplumunun kurucu değerlerini oluşturan aile, kilise ve ulus anlayışıdır. Anlaşıldığı üzere Yorgos ailesinden kopmuş bir gençtir, çok zor durumda olmasına rağmen onların yanına dönmemektedir. Bilgisayarındaki ailesine ait olduğunu anlaşılan fotoğrafları tamamen silmek yerine geri dönüşüm kutusuna atar. Çünkü aile bağını kesmek mümkün değildir, ama aileyi hatırlatan ve aileden kalan anıları ortadan kaldırmak daha kolaydır.

Yorgos'nun dinle ilişkisi ise biraz daha karmaşık görünmektedir. Kanaryası için yem satın aldıktan sonra cebindeki son parasını kilisede mum yakmak için kullanması dindar biri olabileceğini düşündürür. Yorgos mum yaktıktan sonra sıralardan birine oturur ve filmin başında da söylediğini duyduğumuz ilahiyi söylemeye başlar. Kilisede ibadet eden birkaç kişi daha vardır, yaşıı bir kadın Yorgos'nun söylediği ilahi karşısında duygulanır. Ilahi bittikten sonra Yorgos kendi kendine, az önceki kadınla olduğu tahmin edilen, 
uydurma diyalog/monoloğa girer. Bu kurmaca diyalogda kendisine et ve pilav öneren kadına oruç tuttuğunu söyler. "Neden oruç tutuyorsun?" diye sorar Yorgos kadının ağzından ve yine kendisi cevaplar: "Çünkü itiraf etmek istiyorum". Bu noktada mum yakma, ikon öpme, oruç tutma ve itiraf etme gibi Ortodoks kilisesi ritüelleri (Psaras, 2016, s. 211) ile karşı karşıya olduğumuz aşikârdır ancak Yorgos'un uydurma diyaloğu, merhamet ve şefkat üzerine temellenmiş bir kurumun sahteliğini ima ediyor gibidir.

Filmin final sahnesinde Yorgos kanaryasını sakladığı inşaata geri döner. Kuşun kedilere yem olmaması için kafesi Yunan bayrağı ile sarmıştır. Binanın içi ise molozlarla ve başı ya da kolu kopmuş büyük heykellerle doludur. Yorgos en son enkazın ortasında, ulusal kahramanlara ait olabileceğini tahmin edebileceğimiz devrik heykellerin arasında, Yunan ulusunun en saf sembolü Yunan bayrağına sarılmış kuş kafesinin önünde görülmektedir. Kuşun yemini ve suyunu tazelerken, kanarya da neşeyle ötmektedir. Sahnenin düzenlenişi, kendisinin bakımına muhtaç bir canlıyı beslemek ve korumak için elinden gelen çabayı gösteren Yorgos'un karşısına, gençlerine iyi bir iş ve rahat hayat sunmayı başaramamış, adeta geçmişin enkazı altında kalmış bir devleti yerleştirmektedir. Film bittiğinde Yorgos'un günün birinde sistemin öğütlediği gibi kariyer ve aile sahibi bir adam haline gelmeyeceğini çok iyi biliriz ancak hem kendisi hem de kıymetli kanaryası hala hayattadır, hala şarkı söyleyebilirler ve mücadele edebilirler. 0 halde umut vardır.

İşsizliğin sancısını yaşayan bir başka erkek karakter, Babis Makridis'in L filminde tekrar karşımıza çıkar. Ancak L, Kuş Yemi Yiyen Oğlan'ın dramatik öyküsünün aksine absürt denebilecek bir olay örgüsüne sahiptir. Filmin isimsiz ana karakteri profesyonel bir şofördür ve arabasında yaşamaktadır. Arabada uyumakta, yemek yemekte ve eşi ve iki çocuğuyla aracından inmeden otoparkta buluşmaktadır. Ara sıra, kendisini yanlışlıkla ayı zanneden bir avcının öldürdüğü eski meslektaşıyla hayali sohbetler yaptığına tanık oluruz. Anlaşılığı kadarıyla görevi, patronuna en kısa sürede en iyi balı bulup götürmektir. Birkaç aksilik nedeniyle geç kalmaya başlayınca daha başarılı bir başka şoföre işini kaptıır. Bundan sonra gelişen olaylar ise daha tuhaftır. Çok önem verdiği işini kaybetmesinin ardından, kendisi için bir o kadar kıymetli görünen arabasını kullanılmaz hale getirerek bırakır ve motosiklet çetesine katılır. Ancak aradığını orada da bulamaz ve filmin sonunda teknede işe başlar.

Görüldüğü üzere filmin oldukça basit bir hikâyesi vardır, bununla birlikte Yunan yeni dalgasına yakıştııılan 'tuhaf' nitelendirmesinin en çok yakıştığı örneklerden biri olduğunu söylemek mümkündür. 
Yeni dalganın belirleyici özellikleri arasında kabul edilen tiyatral diyaloglar başta olmak üzere, donuk ve ruhsuz oyunculuk, sabit kamera ile yapılmış çekimler izleyiciyi yabancılaştıırken, film içeriği de cevaplanmayı bekleyen sorularla baş başa bırakmaktadır.

Bu çerçevede karakterin hiç inmediği arabasını, dört tarafı ve üstü kapalı, korunaklı, güvenli bir yaşam alanının metaforu olarak düşünmek yol gösterici olabilir. Buna göre, karakterin işini kaybetmesi daha büyük bir anlam kazanmaktadır. Ancak isimsiz kahraman değişiklikten, kendisini ve alıştığı hayatı değiştirmekten korkmadığını çok geçmeden ispatlamakta ve konfor alanını kendi elleriyle yok ederek, tehlike, özgürlük, macera gibi çağrışımları olan motosiklet dünyasına geçiş yapmaktadır. Bile isteye defalarca duvara çarptığı aracından da ilk defa o zaman indiği görülür. Tuhaf bir ritüelle, en az kendisi kadar eksantrik üyelerden oluşan motosikletli gruba katılımı gerçekleşir. Karakterin bu kararını hem umutsuzca bir gruba ait olma ihtiyacının yansıması, hem de kendini yeniden keşfetme arzusu olarak okumak olanaklıdır. Arabasıyla her zaman geçtiği yollardan bu kez motosikletle geçerek, tanıdığı dünyayı başka bir açıdan görmektedir. Kişinin hayatıyla ilgili radikal kararlar almasının cesur ve genellikle umut taşıyan bir hareket olduğu göz önüne alınırsa L'in tüm absürtlüğüne rağmen karamsar bir film olmadığı ortaya çıkmaktadır. Karakter, filmin sonunda teknede işe başladığında tekrar bambaşka bir hayata adım attığı görülür. Karayolundan çok daha öngörülemez, belirsiz bir uzamda sürdüreceği bu yeni hayatı, hiç bilmediği yerlere yapacağı yolculuklardaki serüvenlere gebedir.

Babis Makridis L filmiyle, ülkedeki ekonomik krize doğrudan gönderme yapmamakla birlikte krizin hayatlarını etkilediği insanların varoluşsal sorunlarına dair alegorik bir anlatım sunmaktadır. Vurgulamak gerekirse film söz konusu sorunlara garip mizah anlayışı ve umutlu bir bakış açısıyla yaklaşmakta ve isim bile vermediği işsiz, yalnız karakterin mağduriyetinin altını çizmek yerine onu değişimden korkmayan aktif bir konuma yerleştirmektedir.

\section{Mağduriyetin Cazibesi}

Babis Makridis'in bir sonraki filmi Zavall'da (Oiktos, 2018) ise L'dekinin tersine daha pasif bir karakter karşımıza çıkmaktadır. İsmini yine bilmediğimiz erkek karakter orta yaşlarında, evli ve tek çocuklu bir avukattır. Eşi geçirdiği kaza nedeniyle komada olan karakter, her sabah güne ucuna oturduğu yatağın üzerinde hıçkıra hıçkıra ağlayarak başlamaktadır. Oğluyla birlikte düzenli olarak eşini hastanede ziyaret etmekte, işe gitmekte, evin işleriyle ilgilenmektedir. Bu esnada sık sık kendilerine kek getiren 
komşusuna, kuru temizlemecideki adama, babasına, arkadaşlarına ve hatta müvekkillerine durumunda değişiklik olmayan eşiyle ilgili üzüntüsünü anlatmaktadır. Bu aşamaya kadar ana karakter için üzülmemek ve eşinin olası kaybı için endişelenmemek elde değildir. Ancak günün birinde kadın komadan çıkar ve tamamen iyileşerek eve döner. Yönetmenin izleyicinin beklentileriyle oynadığı yer de tam olarak burasıdır, çünkü karakter kendisinden beklendiği üzere eşinin iyileşmesini neşeyle karşılamaz. Aksine sıkıntı ve hatta hayal kırıklığı içinde olduğu görülmektedir. Hala hastaneye gitmeye devam etmekte, başka hasta yakınlarına özenerek bakmaktadır. Anlaşıldı̆ı üzere acıdan beslenen, mutsuzluktan mutlu olan bir karakter söz konusudur.

Peki, herhangi bir insanın acıyı sevmesi normal midir? Eğer bu, patolojik bir durum olarak kabul edilecekse kökeninde neler aranmalıdır? Bu iki soru Zavalı'nın karakteri özelinde ele alındığında ise bir başka soru daha karşımıza çıkmaktadır. Karakterin gerçekten sevdiği, acı çekmenin kendisi midir yoksa çektiği düşünülen acı nedeniyle başkalarının ona gösterdiği sempati midir? Başka bir deyişle karakter, mağduriyetin cazibesine mi kapılmıştır?

Genel anlamda mağduriyetin, haksızlık sonucu ortaya çıkan bir duruma işaret ettiği hatırlandığında, kimsenin mağdur olmayı arzulamayacağı düşünülebilir. Ancak bir kez o konuma düştükten sonra, mağdur sıfatını taşımayı sürdürmek isteyen ve hatta bunun için yeni mağduriyetler yaratan kişilerden söz etmek olasıdır. Bunu anlamak için 'mağdur' sıfatının kişiyi yerleştirdiği ayrıcalıklı konuma bakmak önemlidir. Çünkü herhangi birisine mağdur etiketi yapıştırıldığı anda, ister istemez gözümüze diğerlerinden farklı görünür. Kişiyi, gerçekten öyle olmasa bile kırılgan, zayıf ve muhtaç bir birey olarak algılayabiliriz. Bu algı ve onun mağdura getirdiği sosyo-ekonomik ayrıcalık, destek, yardım ve ilgi şeklindeki geri dönüşler ise kimi zaman mağduriyet konumunu çekici hale getirebilmektedir. Bu bağlamda Zavallı'daki karakterin başkalarıyla kurduğu ilişkilerde kazandırdığı avantajı statü nedeniyle, mağduriyetini cazibe kaynağı olarak gördüğünü söylemek olanaklıdır. Herhangi bir hastalığın yol açacağı acı ve sıkıntılara katlanmak zorunda olmadan, 'kurban yakını mağdur' konumunun görece konforlu alanında, acıma duygularıyla kendisine yönelmiş şefkat ve ilginin tadını çıkarmaktadır.

Kendisiyle ilgili ismi dâhil fazla bilgi verilmeyen karakterin geçmişi ile ilgili çıkarsama yapmak gerekirse, hayatının eşi komaya girmeden önceki döneminde muhtemelen çevresindekilerin kendisine arzuladığı şekilde özel bir değer vermeyip ayrıcalıklı bir ihtimam göstermediği ve bunun sonucunda 
değersiz benlik algısı geliştirdiği söylenebilir. Ancak 'komadaki eşinin yasını tutan koca' statüsüyle birlikte, başkalarının yarattığı 'önemsiz' olma duygusu yine başkalarının gösterdiği ilgi ve duygusal yakınlık sonucunda yerinden edilmiştir. Söz konusu ilgi ve yakınlık teselli sözleriyle olduğu kadar, kimi zaman bir kek, kimi zaman da sırta sürülen güneş yağı formatında sunulmakta ve karakterin kendisini tekrar önemli hissetmesini sağlamaktadır. Bununla birlikte eşi sağlığına kavuştuktan sonra, sabahları kapının önünde komşusunun getirmesini beklediği kek gelmez olur, artık acıyan bakışların nesnesi değildir, tüm ilgi eşinin üzerine yönelmiştir. Bu yüzden düzenli olarak uğradığı kuru temizlemeciye eşinin iyileşip taburcu olduğundan bahsetmez. Karakter, başkalarının ona acımasına, mağdur olmanın kendisine geri kazandırdıklarına o kadar bağlanmıştır ki farklı çözümler aramaya başlar. Artık eskisi gibi hıçkıra hıçkıra ağlamayı beceremediği için gözyaşı gazı kullanarak ağlamayı dener önce. Bu arada yaşlı babaları cinayete kurban giden iki müvekkilinin acısına ve başkalarının onlara duyduğu acımaya giderek daha fazla özendiği anlaşılmaktadır. Kaybolduğu izlenimi bırakmak amacıyla denize attığı köpeği için çevresinden sempati bekler. Ama insanların kayıp bir köpek için göstereceği acıma sınırlıdır ve karakter için yeterli olmayacaktır.

İsimsiz karakterin özellikle de babasının ilgisini ve acıma duygusunu kazanmak istediği anlaşıımaktadır. Eşi henüz komadayken, babasına duyduğu üzüntüyü ısrarla anlatmaya çalıştığı sahnede yaşlı adamın alakasız veya soğuk cevaplar verdiği görülmektedir. Başta yaşlı adamın bu tavrının oğlunun acısına duyduğu kayıtsızlıktan mı, yoksa oğlunun mağdur olmaya duyduğu saplantıyı bilmesinden mi kaynaklandığı belirsizdir. Adam aynı tavrı oğlu, köpeği kaybolduğu için dert yandığı zaman da sürdürür, dönüp yüzüne bile bakmadığı oğluna "Geri gelecektir. Gelmezse de yeni bir tane alabilirsin" der. Yaşlı adamın bu soğuk ve kuru mantığı, ana karakteri yetiştirirken de kullandığı düşünülürse, karakterin babasından hiçbir zaman göremediği duygusal yakınlığı başkalarından görmek için duyduğu umutsuz ihtiyaç anlaşılabilir gelecektir. Ancak bu yakınlığı, sadece mağduriyetin kendisine sağladığı avantajı rol aracılığıyla edinebileceğine inanmıştır. Sonunda bulduğu kesin çözüm ise, üstlendiği davadaki cinayeti kopyalayarak babasını, eşini ve muhtemelen oğlunu öldürmek olur.

Mağdurun Dili adlı çalışmasında "mağdur-cani" kavramını ortaya atan Nurdan Gürbilek "adam yerine konmama yazgısının" mağdur kişinin içinde "hınçlı öteki" yarattığını belirtmektedir (2018, s. 150). Yazara göre mağdur-cani, aşağılanmışlığına şiddetle yanıt veren kişidir. Bu doğrultuda Zavallının karakterinin babasını öldürmesi benzer bir mağdur psikolojisiyle açıklanabilir. Bununla birlikte eşini ve 
belki çocuğunu da katletmesi tamamen mağduriyetin ona sağladığı avantajlardan ve güçten sonuna kadar yararlanmak istemesi ve bu yolda her şeyi göze almasıyla ilgilidir. Dolayısıyla bu patolojik karakterin aslında, filmin isminin de işaret ettiği gibi, 'mağdur-zavallı' olduğunu söylemek daha doğru olacaktır. Ayrıca Yunan yeni dalgasının 'aile'ye ve 'baba'ya yönelik eleştirilerinin Zavall'nın karakterinin yıkıcı eylemlerinde somutlaştığını eklemek gerekmektedir.

\section{SONUÇ}

Siegfried Kracauer'in dediği gibi "Bir ulusun filmleri o ulusun kafa yapısını diğer tüm sanat dallarından daha iyi yansıtır" (2011). Başka bir deyişle sinema her zaman en önemli kültürel dışavurum araçlarından biri olmuştur. Yunan yeni dalgası filmlerinin önemli örneklerine bakıldığında da krizdeki bir toplumun sosyal ve psikolojik yapısının yansımaları görülebilmektedir. Söz konusu filmleri travma ve özellikle kayıp duygusuyla ilişkilendiren Nikolaidou'ya göre bu kayıp sevilen birisiyle, kontrol hissiyle, saç ya da parmak gibi beden parçalarıyla ve hatta statüyle ilişkili olabilir $(2014,5$. 40). Yeni dalga filmlerinin sosyo-ekonomik alanda gerçekleşenlerle eş zamanlı olarak üretildiği göz önünde tutulduğunda, Nikolaidou'nun bahsettiği travmanın geçmişle ilgili değil, güncel tarihle bağlantılı olduğu anlaşılmaktadır. Bu bağlamda ekonomik krizin Yunan toplumunda neden olduğu maddi ve manevi kayıpların ve buna bağlı travmaların kendi mağdurunu ya da mağdurlarını yarattığını söylemek mümkündür.

Papadimitriou'nun işaret ettiği üzere kriz döneminde medyada yer alan ülke hakkındaki olumsuz temsiller, Yunanları ya global neo-liberalizmin kurbanı ya da kötü finansal yönetimin ve yozlaşmanın sorumlusu olarak tasvir etmektedir $(2014$, s. 2). Yunan yeni dalgasının krize ve onun neden ve sonuçlarına bakışı ise, ağırlıklı olarak, Yunan kimliğini oluşturan 'anayurt, din ve aile' üçgeni çerçevesinde olmuştur. Buna göre anayurt kavramının aşırı milliyetçiliği ve ırkçıllığı, dini inanç sisteminin gericiliği ve muhafazakârlığı, ailenin ise ataerkil baskıyı ve şiddeti yeniden ürettiğine yönelik sert eleştiriler Yunan yeni dalga filmlerinin temelini oluşturmaktadır. Bu kapsamda yeni dalganın ana karakterleri ırkçı̆ı̆ın, ötekileştirmenin, tacizin, tecavüzün, ensestin, işsizliğin ve kimlik krizinin mağdurları olarak karşımıza çıkmaktadır. Yeni dalga filmlerinde geçmişin kurucu değerleri, yeni nesil için parlak bir gelecek vaat etmekten uzak ve bu nedenle de mevcut bağlarını koparması gereken mağduriyet kaynakları şeklinde temsil edilmektedir. 
Buna göre özetlemek gerekirse, çalışmada incelenen Köpekdişi ve Şiddet Güzeli filmleri, ailenin koruyucu ve kollayıı olma işlevini yitirdiğine, ataerkil baskıyı yeniden üreten yapısına ve aile içi psikolojik ve fiziksel şiddetin görünmezliğine işaret etmektedir. Plato'nun Akademisi ve Xenia filmlerinde ise antik döneme kadar uzanan görkemli Yunan medeniyeti üzerine inşa edilen milliyetçiliğ̈in ve ırkçlığın yarattığı yabancı korkusu ve kimlik krizi vurgulanmaktadır. Kadının Fendi toplumdan dışlanan ve ötekileştirilen queer bireylerin mağduriyetine değinirken; Kuş Yemi Yiyen Oğlan ve $L$ filmlerinde işsizliğin ve parasızlı̆ıın mağduriyet yaratan konular olarak temsil edildiği görülmektedir. Zavalı filmi ise 'mağdur-zavallı' ana karakteri üzerinden mağduriyetin cazibesini ele almaktadır. Bu doğrultuda, Yunan yeni dalgasının önemli örnekleri arasında yer alan bu filmlerin, birbirinden farklı öyküler anlatsalar da mağduriyet paydasında buluştuğunu söylemek mümkündür.

Her ne kadar akımın önde gelen yönetmenleri tarafından ortak bir hareket olduğu kabul edilmese de, eleştirmenler Yunan yeni dalgasını oluşturan belli karakteristik özellikler üzerinde hemfikirdir. Bu çalışmada söz konusu ortak özellikler arasında 'mağdur karakterlerin' de yer aldığı gösterilmeye çalışılmış ve mağduriyet konusunun yeni dalga filmleri için tematik çerçeve olarak kullanılabileceği sonucuna varılmıştır. Bununla birlikte yeni dalga yönetmenlerinin, filmlerindeki mağdur karakterler için her zaman çözüm yolu sunmadığı ya da çözümün geçmişin değerlerinden kopmakta yattığına işaret ettiği ama bunun nasıl yapılması gerektiğini belirsiz bıraktığı görülmektedir. Yine de Yunan yeni dalgasının, krizin mağdur ettiği toplumun alegorik yansımasını sunarken, karakterlerin mağduriyetinin sebeplerini (bazen tuhaf da olsa) cesur, sert ve yenilikçi biçimde seyirciye göstermesi önemli ve dikkate değer bir adım olarak değerlendirilmelidir.

\section{EXTENDED ABSTRACT}

Since about 2010, a new movement of films has been born in Greece, affecting international cinema culture. The pioneers of this movement, called the Greek New Wave by film critics, are Yorgos Lanthimos's Dog Tooth (Kynodontas, 2009) and Attenberg (2010), directed by Athina Rachel Tsangari. The 'weirdness', which is thought to be one of the common features of the two films, has led to the movement also being characterized as the Greek Weird Wave.

Political, economic and social developments in Greek society are thought to be in the background of the Greek new wave. Therefore, it is important to examine the developments in Greek society after 
2000 and especially the Euro Zone crisis in 2008, which also affected Greece. Since the early 2000's, economic scandals, corruption, the migrant problem, high crime rates, xenophobia and racism, street riots and vandalism affecting other major cities, especially Athens, have had negative effects on Greek society (Chalkou, 2012; Varmazi, 2019). Therefore, the films evaluated in the new wave were born from a society in crisis and tell about a society in crisis, in other words, how people experience the crisis. There is not much direct reference to the economic crisis in these films, but it is possible to say that the sense of frustration, imbalance, shock, loss and pain that dominates the overall films corresponds to the psychological state of a society in crisis.

Common characteristics of the films that make up the Greek new wave include cinematographic features such as minimal narration, still and fixed camera use, long shots, slow editing, silence, mechanical and expressionless acting. In content, it is seen that they tell stories that develop around themes such as family, power, patriarchy, gender, identity, body, violence and loss. This study argues that the concept of 'victimization' should be added to these themes and in this respect, aims to examine the characters of new wave films within the framework of victimization.

While the concept of victimization is generally considered to be related to the phenomenon of crime, there may be situations that are not considered a crime by law but create their victims. Accordingly, it is seen that the Greek new wave is about criminal acts such as harassment and rape, as well as characters victimized by patriarchal order, racism, ultranationalist rhetoric, marginalization and unemployment. The eight films selected in the study were examined within this framework; the family, racism, patriarchy, marginalization and unemployment, which are among the main issues criticized by the Greek new wave, have been identified as the main sources of victimhood. According to this; patriarchal family in Dogtooth and Miss Violence (2013, dir. Alexandros Avranas) films, nationalism and racism in Plato's Academy (Akidimia Platonos, 2009, dir. Flippos Tsitos) and Xenia (2015, dir. Panos H. Koutras) films, marginalization in Strella (2009, dir. Panos H. Koutras), unemployment in Boy Eating the Bird's Food (To Agori Troei To Fagito Tou Pouliou, 2012, dir. Ektoras Lygizas) and L (2012, dir. Babis Makridis) films evaluated as victimization issues and finally, the movie Pity (Oiktos, 2018, dir. Babis Makridis) was discussed in the context of the appeal of victimization. 
In the films mentioned, the children who were molested and raped by their fathers, socially oppressed homosexuals, young people subjected to and excluded from racial violence, and unemployed men are represented as victims of the patriarchal family, traditional and nationalist Greek society. Accordingly, it is possible to see that the slogan "Fatherland, Religion, Family" (Psaras, 2016), which summarizes the status of being Greek, is criticized harshly in the new wave films. The fatherland in the slogan is to send it to Greek identity, which dates from the glorious ancient Greek past to the modern era and is idealized with nationalist values. Religion points to the belief system represented by the Orthodox Church, which has always been known to have a great influence on social and political life in Greece. Family, on the other hand, complements the slogan as an ideal institution shaped by conventionality and etheled by patriarchal ideology. In contrast, Greek new wave directors criticize nationalism, patriarchal family, conservative values and the official discourse that produces them, addressing them as part of racism, marginalization, harassment, rape and incest. In other words, the founding values of the past have become sources of victimization of the present.

Accordingly, it is seen that the families encountered in the new wave films are treated as microuniverses reflecting Greek society. Dysfunctional families in these films represent power relations, violence and gender dynamics in society. The films Dogtooth and Miss Violence show the new wave's view of the family, with narratives focusing on violence and persecution hidden in domestic relationships, and overprotective and abusive families.

The victim characters of the Greek new wave do not only appear as members of the patriarchal family. The nationalism embodied in the concept of fatherland in the slogan of Greek identity also creates the victims of racism and xenophobia. While Plato's Academy emphasizes that feelings such as hatred, fear, and resentment towards ethnic groups who are marginalized and therefore victimized on many issues are largely due to cultural productions, in Xenia, we see the representation of a country based on xenophobia, racism and nationalism.

Strella discusses sexual identity, transsexuality, incest and family issues from a bold point of view. Queer individuals, who are excluded from society, reprehensible, marginalized and therefore can say that they are victims, have found a positive place in the film. 
It is also possible to come across characters victimized by unemployment and lack of money in the Greek new wave. The first of these examples is in the film Boy Eating the Bird's Food as a representative of the generation that experienced the devastating and abrasive consequences of the Greek economic crisis. Another example, L, gives an allegorical narrative of the existential problems of people whose lives are affected by the crisis.

Pityalso deals with the issue of victimhood, but with its main character caught up in the lure of victimhood, it is at a different point than other new wave examples. The character of the film considers his victimization as an attraction because of the advantageous status he has gained in his relationships with others.

As a result, it is seen that the Greek new wave's view of the crisis and its causes and consequences is predominantly within the framework of the triangle of 'fatherland, religion and family', which constitutes Greek identity. Accordingly, the ultranationalism and racism of the concept of fatherland, the reactionism and conservatism of the religious belief system, and the harsh criticism that the family is re-producing patriarchal oppression and violence form the basis of Greek new wave films. In this context, the main characters of the new wave appear as victims of racism, marginalization, harassment, rape, incest, unemployment and identity crisis.

\section{KAYNAKÇA}

Altunışık, R., Coşkun, R., Yıldıım , E., \& Bayraktaroğlu, S. (2010). Sosyal Bilimlerde Araştırma Yöntemleri: SPSS Uygulamalı. Sakarya: Sakarya Yayınclık.

Bilis, A. (2018). Yorgos Lanthimos filmlerinde distopyan temsiller. Akdeniz Üniversitesi Iletişim Fakültesi Dergisi(29), 54-72.

Bradshaw, P. (2011). Attenberg-review. The Guardian: http://www.theguardian.com/film/2011/sep/01/attenberg-film-review adresinden alındı

Chalkou, M. (2012). A new cinema of 'emancipation': Tendencies of independence in Greek cinema of the 2000s. Interactions: Studies in Communication \& Culture, 3(2), 243-261.

Chaplinsky, J. (2012). Yorgos Lanthimos is not the leader of the Greek new wave: An interview with the director of Alps and Dogtooth. Screenanarchy: https://screenanarchy.com/2012/07/yorgos-lanthimosis-not-a-prude-an-interview-with-the-director-of-alps-and-dogtooth.html adresinden alındı

Freud, S. (2011). Haz ilkesinin ötesinde-Ben ve id. (A. Babaoğlu, Çev.) İstanbul: Metis Yayınları.

Gürbilek, N. (2018). Mağdurun dili. İstanbul: Metis Yayınları. 
Homeros. (2008). Odysseia. İstanbul: Can Yayınları.

Kracauer, S. (2011). Caligari'den Hitler'e: Alman sinemasının psikolojik tarihi. (E. Yılmaz, Çev.) Ankara: De Ki Yayınları.

Nikolaidou, A. (2014). The performative aesthetics of the 'Greek new wave'. Filmicon: Journal of Greek Film Studies, 2, 20-44.

Nochimson, M. (2012). Bir dünya sinema. (Ö. Yaren, Çev.) Ankara: De Ki Yayınları.

Papadimitriou, L. (2014). Locating contemporary Greek film cultures: past, present, future and the crisis. FILMICON: Journal of Greek Film Studies(2), 1-19.

Poupou, A. (2018). The poetics of space in the films of the new wave of contemporary Greek cinema. PARABASIS Journal of the Department of Theatre Studies of the National and Kapodistrian University of Athens, 16(1), 295-313.

Psaras, M. (2016). The queer Greek weird wave: ethics, politics and the crisis of meaning. Cham: Palgrave Macmillan. doi:10.1007/978-3-319-40310-6

Rose, S. (2011). Attenberg, Dogtooth and the weird wave of Greek cinema. The Guardian: https://www.theguardian.com/film/2011/aug/27/attenberg-dogtooth-greece-cinema adresinden alındı

Smith , W. (Dü.). (1870). Dictionary of Greek and Roman Biography and Mythology Vol. III. London: John Murray.

Türk Dil Kurumu. (1998). Türkçe sözlük (Cilt 2). Ankara.

Türk Hukuk Kurumu. (1991). Türk hukuk lugatı. Ankara: Başbakanlık Basımevi.

Varmazi, E. (2019). The weirdness of contemporary Greek cinema. Film International(87), 40-49. 